\title{
Synthesis of High-Sulfur Polymers by Redox Copolymerization, using Elemental Sulfur with Pyrrole
}

\section{GAUKHAR BISHIMBAYEVA ${ }^{1 *}$, GALINA PROZOROVA ${ }^{2}$, DINARA ZHUMABAYEVA ${ }^{1}$, SVETLANA KORZHOVA ${ }^{2}$, IRINA MAZYAR ${ }^{2}$, ARAILYM NALIBAYEVA ${ }^{1}$ and ULDANA KYDYRBAYEVA ${ }^{1}$}

1D.V. Sokol'skii Institute of Fuels, Catalysis \& Electrochemistry, Almaty, Kazakhstan.

${ }^{2}$ A. E. Favorsky Irkutsk Institute of Chemistry, Siberian Branch of the Russian Academy of Sciences, Irkutsk, Russia.

${ }^{*}$ Corresponding author E-mail: g.bishimbayeva@ifce.kz

http://dx.doi.org/10.13005/ojc/340230

(Received: August 24, 2017; Accepted: January 10, 2018)

\begin{abstract}
In this work we discuss the results of obtaining new high-sulfur polymers based on pyrrole and elemental sulfur. For the synthesis of high-sulfur based on pyrrole polymers was used method of co-oxidation of pyrrole and polysulfone, previously generated in situ from an aqueous solution of sodium polysulphide in the presence of $\mathrm{H}_{2} \mathrm{O}_{2} / \mathrm{FeCl}_{3} / \mathrm{HCl}$ oxidation system. Depending on the reaction conditions, the addition of reaction mixture of gelatin or surfactant, sulfur-pyrrole polymers with a high sulfur content were obtained: from 75.2 to $87.9 \%$. The conditions for carrying out the reaction are selected, which allow varying the sulfur content in obtained copolymers. The physico-chemical properties and microstructures of the obtained copolymers were studied. It is established that the synthesized copolymers have thermal stability, semiconducting properties, have a developed microstructure, with sufficiently small microparticles of narrow polydispersity and are promising for the development of active cathode materials of modern rechargeable lithium current sources.
\end{abstract}

Keywords: Tengiz sulfur, Lithium-sulfur batteries, Copolymerization of pyrrole with sulfur.

\section{INTRODUCTION}

The oil and gas industry is currently developing both in the direction of increasing oil and gas production, and in the direction of creating and implementing innovative technologies for the processing of its waste. One of the associated waste in the extraction of oil and gas is sulfur. At present, huge reserves of sulfur formed as a result of primary oil refining have accumulated in places of open storage of oil companies. An inevitable consequence of this is the technogenic impact on 
environmental objects ${ }^{1,2}$. The world market of sulfur is projected to have a stable tendency to exceed the production of sulfur over its sales ${ }^{3}$. Therefore, there is a need to develop modern ways of its utilization into new polymeric sulfur composites that have a number of valuable properties that will increase the world demand for elemental sulfur. One of the promising ways of partially solving the problem of sulfur utilization is the development of new technologies for producing electrically conductive, electrochemically active polymeric sulfur composites for their application as the main components of active cathode materials in modern lithium-sulfur batteries ${ }^{4-13}$. With the development of portable electronic devices, as well as the increasing interest in the world of electric vehicles and large-scale energy storage applications, great attention is paid to lithium-sulfur (Li-S) batteries due to their high energy density and theoretical capacity $^{14,15}$. The lithium-sulfur battery has a high theoretical energy density of $2600 \mathrm{~W} \cdot \mathrm{h} / \mathrm{kg}$, which shows a great potential among rechargeable batteries ${ }^{16,17}$. Thus, the development of technology and investigation of new high-sulfur materials has a high scientific and practical significance. In order to develop original methods for obtaining new high-sulfur polymers that are promising for the development of active cathode materials of modern rechargeable lithium current sources, the authors have studied redox processes of copolymerization of elemental sulfur with pyrrole, leading to the formation of colloidal cross-linked polymers. New high sulfur sulfur-based polymers (Tengizchevroil company) and pyrrole have been obtained, and the physico-chemical properties and microstructure of synthesized high-sulfur polymers have been studied.

\section{MATERIALS AND METHODS}

Powdered elemental sulfur from the Tengiz field (Kazakhstan), $\mathrm{Na}_{2} \mathrm{SO}_{4} 9 \mathrm{H}_{2} \mathrm{O}$ (p.a.), $\mathrm{FeCl}_{3} 6 \mathrm{H}_{2} \mathrm{O}$ (c.p., $\mathrm{HCl}, \mathrm{H}_{2} \mathrm{O}_{2}$ (without additional purification) was used to synthesize high-sulfur polymers based on pyrrole. The pyrrole was purified before synthesis by distillation under reduced pressure. Physicochemical properties of the obtained high-sulfur polymers based on pyrrole were studied. The infrared spectra of the samples were recorded on Bruker Vertex 70 Spectrometer in the $400-4000 \mathrm{~cm}^{-1}$ region (in $\mathrm{KBr}$ tablets). Thermogravimetric analysis of the samples was performed on Q-1500 derivatograph of Paulik-Paulik-Erdei system (MOM, Hungary), sample weight - $50 \mathrm{mg}$, DTA sensitivity $-1 / 5$, heating rate $-10^{\circ} \mathrm{C} / \mathrm{min}$. The specific electric conductivity of the copolymers was measured on direct current using a standard "E6-13A" terameter. The investigating samples were prepared in the form of tablets by pressing under a pressure of $700 \mathrm{~kg} / \mathrm{cm}^{2}$. To carrying out comparative investigations of the microstructure of synthesized high-sulfur pyrrole-based polymers, X-ray dispersive spectral microanalysis using the TM 3000 Hitachi electron microscope was used.

\section{RESULTS AND DISCUSSION}

High-sulfur pyrrole-based polymers were synthesized by the combined oxidation of pyrrole and polysulfone, previously generated in situ from an aqueous solution of sodium polysulphide in the presence of oxidizing system, commercial surfactant and colloidal stabilizer (gelatin). The stabilizer was used as a pre-prepared aqueous solution. The oxidation system $\mathrm{H}_{2} \mathrm{O}_{2} / \mathrm{FeCl}_{3} / \mathrm{HCl}$ includes $33 \%$ solution of $\mathrm{H}_{2} \mathrm{O}_{2}, \mathrm{FeCl}_{3} 6 \mathrm{H}_{2} \mathrm{O}$ and $2 \mathrm{~N} \mathrm{HCl}$ solution. Colloidal activated sulfur was prepared in situ from sodium polysulphides $\mathrm{Na}_{2} \mathrm{Sx},(x=4.0-4.5)$.

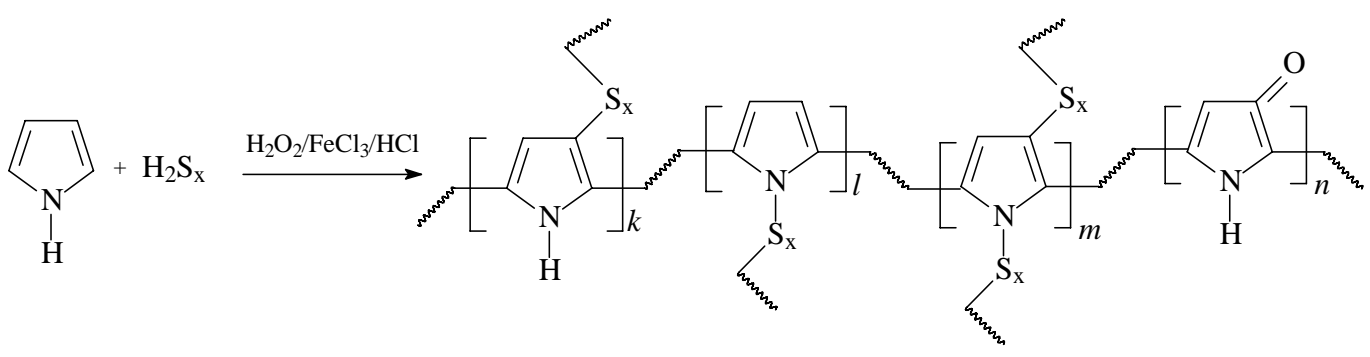

Scheme 1 
Table 1: The synthesis conditions and yield of polymers based on pyrrole and elemental sulfur

\begin{tabular}{|c|c|c|c|c|}
\hline $\begin{array}{l}\text { Copolymer } \\
\text { cipher }\end{array}$ & $\begin{array}{l}\text { Composition of the } \\
\text { reaction mixture }\end{array}$ & $\begin{array}{c}\text { Temperature of } \\
\text { reaction, }{ }^{\circ} \mathrm{C}\end{array}$ & $\begin{array}{l}\text { Time of } \\
\text { reaction, } \mathrm{h}\end{array}$ & $\begin{array}{l}\text { Yield, } \\
\%\end{array}$ \\
\hline Pys 1 & $\begin{array}{l}\text { polysulphide, } \\
\text { pyrrole, } \mathrm{HCl}, \mathrm{FeCl}_{3} \cdot 6 \mathrm{H}_{2} \mathrm{O} \text {, } \\
\mathrm{H}_{2} \mathrm{O}_{2} \text {, surfactant, gelatin }\end{array}$ & $\begin{array}{c}25-47 \\
\text { (self-heating) }\end{array}$ & 4 & 80.3 \\
\hline PyS 2 & $\begin{array}{l}\text { polysulphide, } \\
\text { pyrrole, } \mathrm{HCl}, \mathrm{FeCl}_{3} \cdot 6 \mathrm{H}_{2} \mathrm{O} \text {, } \\
\mathrm{H}_{2} \mathrm{O}_{2} \text {, surfactant }\end{array}$ & $\begin{array}{c}25-53 \\
\text { (self-heating) }\end{array}$ & 4.5 & 71 \\
\hline PyS 3 & $\begin{array}{l}\text { polysulphide, pyrrole, } \\
\mathrm{HCl}, \mathrm{FeCl}_{3} \cdot 6 \mathrm{H}_{2} \mathrm{O}, \mathrm{H}_{2} \mathrm{O}_{2}\end{array}$ & $\begin{array}{c}25-67 \\
\text { (self-heating) }\end{array}$ & 3 & 79.2 \\
\hline PyS 4 & $\begin{array}{l}\text { polysulphide, pyrrole, } \\
\mathrm{HCl}, \mathrm{FeCl}_{3} \cdot 6 \mathrm{H}_{2} \mathrm{O}, \mathrm{H}_{2} \mathrm{O}_{2}\end{array}$ & $\begin{array}{c}25-58 \\
\text { (self-heating) }\end{array}$ & 3 & 80.8 \\
\hline Pys 5 & sulfur, pyrrole, & $160-165^{\circ} \mathrm{C}$ & 15 & 79.4 \\
\hline PyS 6 & sulfur, pyrrole, & $210-220^{\circ} \mathrm{C}$ & 6 & 76.2 \\
\hline
\end{tabular}

Table 2: Elemental composition and melting temperature of polymers based on pyrrole and elemental sulfur

\begin{tabular}{lcccccc}
\hline \multirow{2}{*}{ Sample cipher } & \multicolumn{5}{c}{ Elemental analysis } & $\mathrm{T}_{\text {melting }}{ }^{\circ} \mathrm{C}$ \\
\hline & $\mathrm{C}$ & $\mathrm{H}$ & $\mathrm{N}$ & $\mathrm{Cl}$ & $\mathrm{S}$ & \\
PyS 1 & 6.2 & 0.6 & 1.1 & 1.3 & 76.5 & $170-255$ \\
PyS 2 & 8.1 & 0.4 & 1.8 & 7.0 & 79.5 & $167-210$ \\
PyS 3 & 9.3 & 0.5 & 2.1 & 7.9 & 76.2 & $170-240$ \\
PyS 4 & 7.3 & 0.4 & 1.7 & 0.4 & 76.6 & $165-215$ \\
PyS 5 & 7.4 & 1.3 & 1.5 & 1.7 & 87.9 & $167-210$ \\
PyS 6 & 14.3 & 1.7 & 3.3 & 1.7 & 75.2 & $169-220$ \\
\hline
\end{tabular}

In the result of varying the reaction conditions, sulfur-pyrrole copolymers were obtained in the form of powders of dark brown color with different sulfur contents (Fig. 1, Table 1, 2).

Depending on the reaction conditions, the nature of the oxidation system, the addition of gelatin or surfactant to the reaction mixture, sulfur-pyrrole polymers with a high sulfur content were obtained: from 75.2 to $87.9 \%$.

In the IR spectra of high-sulfur pyrrolebased polymers (Fig. 2) there are characteristic absorption bands $\left(\mathrm{cm}^{-1}\right)$ : 1714 ( $\left.\mathrm{v}, \mathrm{C}-\mathrm{O}\right) ; 1449$ ( $v, C=C$ of the polypyrrole moiety); 1334, 1234, $781(v, \mathrm{C}=\mathrm{C}-\mathrm{H}) ; 1029,1017(v, \mathrm{O}=\mathrm{S}) ; 791,781$ ( $v, \mathrm{C}=\mathrm{C}-\mathrm{H}) ; 659,619$ ( $v, \mathrm{C}-\mathrm{S}) ; 468$ ( $v, \mathrm{~S}-\mathrm{S})$.
While investigating the electrical conductivity of the obtained high-sulfur pyrrole-based polymers, it was found that they have a specific electrical conductivity of the order of 10-13 S/cm, corresponding to high-resistance organic semiconductors (Table 3 ).

According to the thermogravimetric analysis results, the polymers obtained are highly resistant to thermal-oxidative degradation (up to $210-230^{\circ} \mathrm{C}$ ) (Figurs. 3).

Using the X-ray dispersive spectral microanalysis method were carried out microstructure investigations of synthesized high-sulfur polymers based on pyrrole. Typical micrographs of the obtained high-sulfur polymers are presented in Figure. 4. 


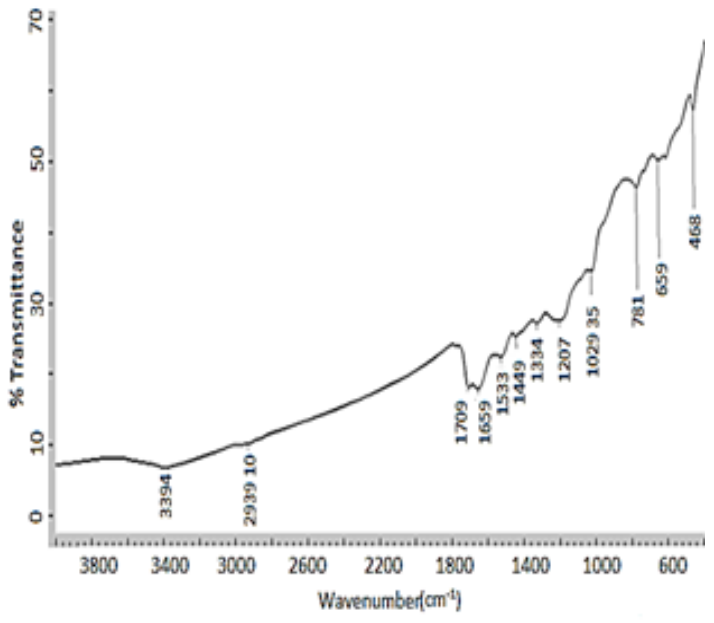

(a)

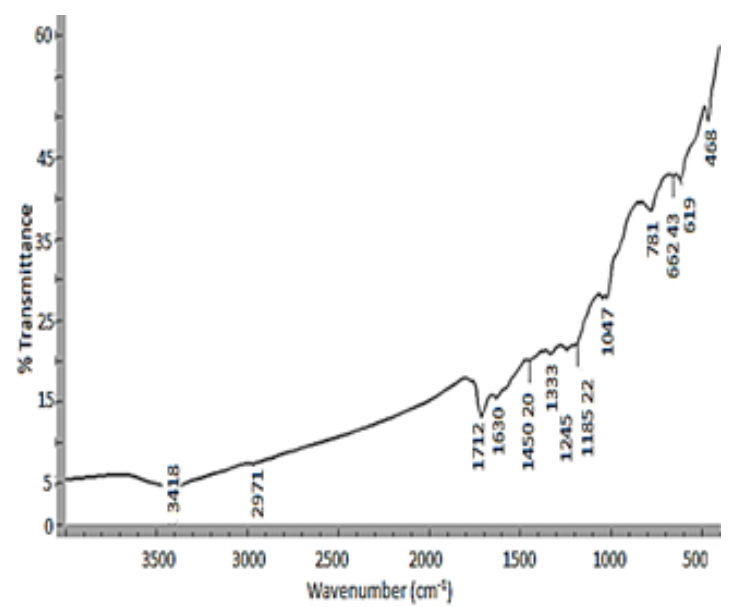

(c)

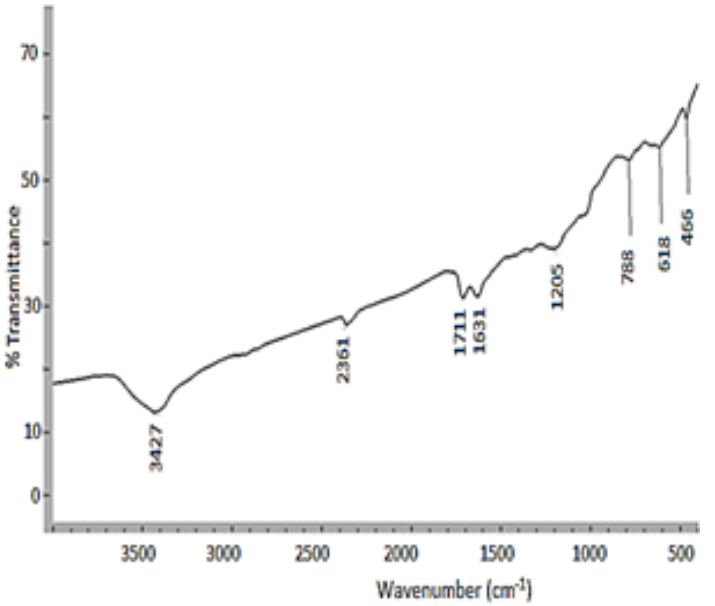

(b)

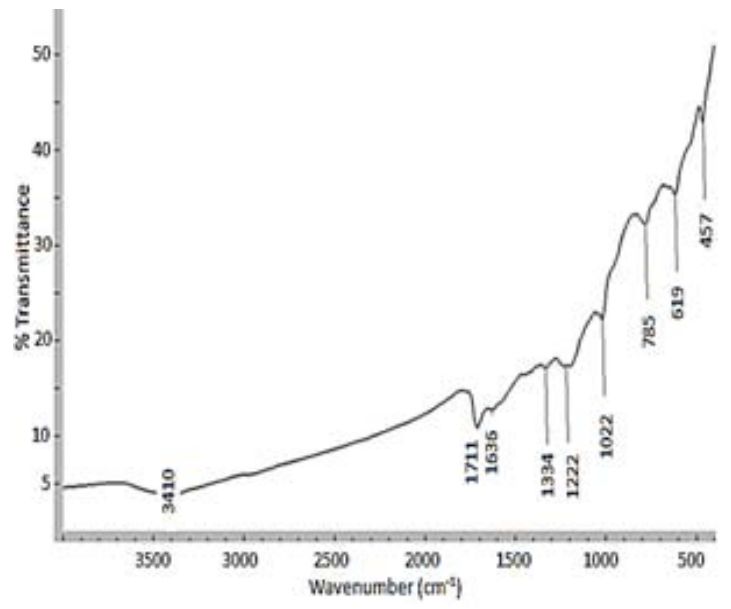

(d)

Fig. 2. IR spectra of high-sulfur polymers based on pyrrole: (a) PyS 1, (b) PyS 2, (c) PyS 3, (d) PyS 4

Table 3: Specific electrical conductivity (s) and thermogravimetric analysis of high-sulfur polymers based on pyrrole

\begin{tabular}{lccc}
\hline Sample cipher & Content of S, \% & TGA, ${ }^{\circ} \mathrm{C}$ & $\mathrm{s}, \mathrm{S} / \mathrm{cm}$ \\
\hline PyS 1 & 76.5 & $\sim 220$ & $1.9 \times 10^{-13}$ \\
PyS 2 & 79.9 & $\sim 230$ & $3.8 \times 10^{-13}$ \\
PyS 3 & 76.4 & $\sim 210$ & $2.1 \times 10^{-13}$ \\
PyS 4 & 76.6 & $\sim 210$ & $3.3 \times 10^{-13}$ \\
PyS 5 & 87.9 & $\sim 220$ & $7.2 \times 10^{-13}$ \\
PyS 6 & 75.2 & $\sim 230$ & $4.5 \times 10^{-13}$ \\
\hline
\end{tabular}




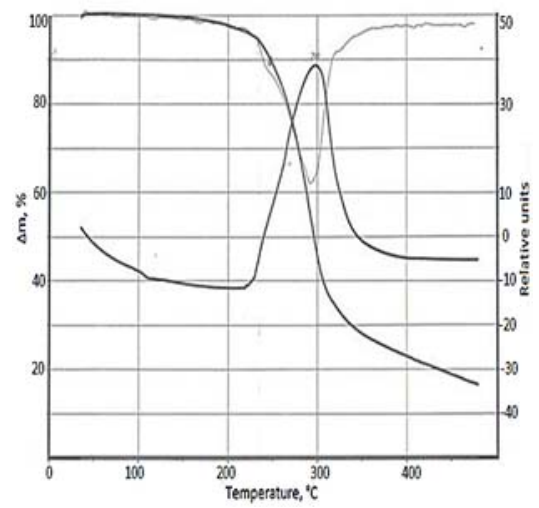

(a)

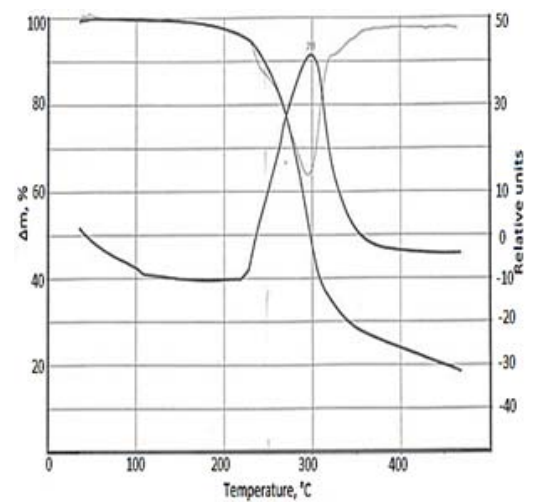

(c)

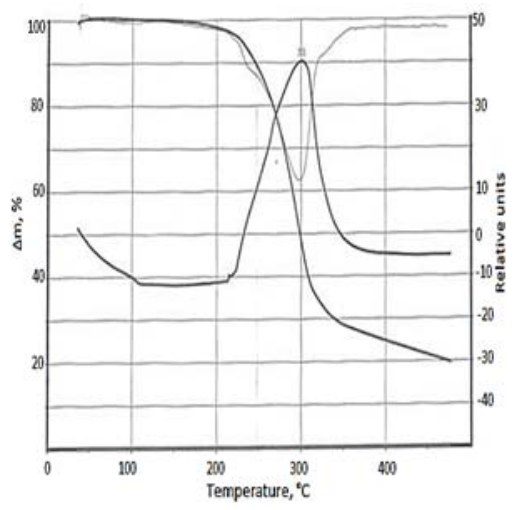

(b)

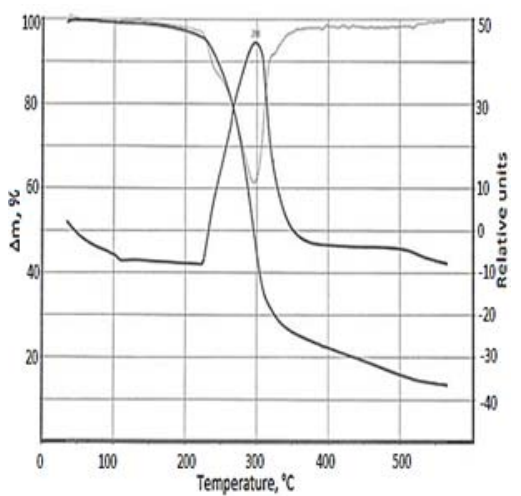

(d)

Fig. 3. Thermogravimetric analysis curves of high-sulfur polymers based on pyrrole: (a) PyS 1, (b) Pys 2, (c) PyS 3, (d) Pys 4

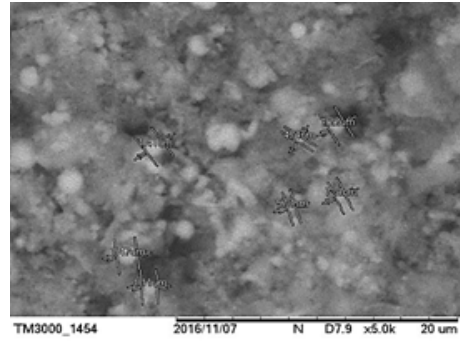

(a)

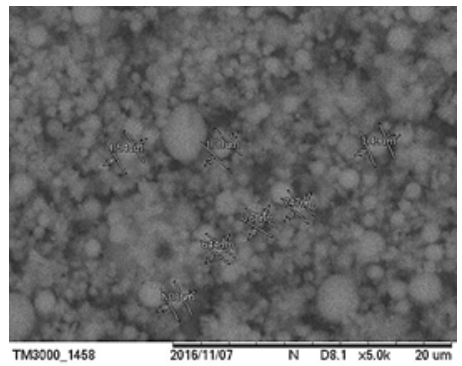

(c)

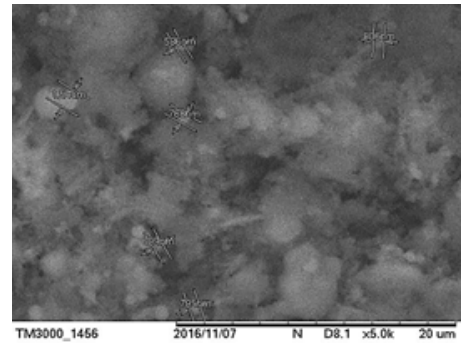

(b)

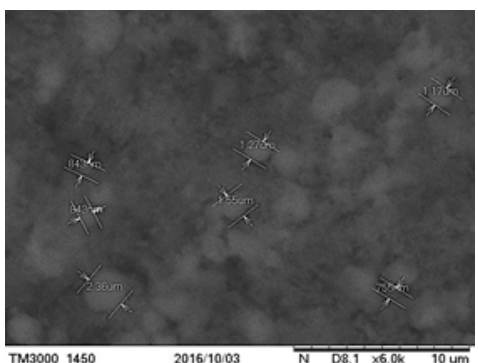

(d)

Fig. 4. Micrographs of high-sulfur polymers based on pyrrole: (a) PyS 1 (474 nm $-1.47 \mu \mathrm{m})$,

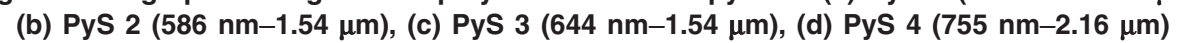


The obtained results indicate that the synthesized copolymers have developed microstructure with rather small microparticles sizes of narrow polydispersity in the range of $474 \mathrm{~nm}$ to $1.54 \mu \mathrm{m}$

\section{CONCLUSION}

Technological methods for the synthesis of high-sulfur polymers based on the redox copolymerization of elemental sulfur with pyrrole have been developed. Conditions for carrying out the reaction have been found, which make it possible to vary the sulfur content of the obtained materials. It has been established that synthesized high-sulfur polymers have thermal stability, semiconductor properties, developed surface morphology and are promising for the development of active cathode materials of modern rechargeable lithium current sources.

\section{ACKNOWLEDGEMENT}

The work was carried out under the project 5354/GF4 "Development of innovative materials based on modified polymeric sulfur with improved electrically conductive, redox-active, binding and astringent properties" of Education and Science Ministry Committee of Kazakhstan Republic.

\section{REFERENCES}

1. Clark, P.D.; Davis, P.M.; Marriott, R.A.; Wan, H.H.; Bernard, F. ASR Quarterly Bulletin., 2008, XLV, $56-65$.

2. Clark, P.D.; Bernard, F.; Davis, P.M. ASR Quarterly Bulletin., 2004, XL No. 4, , 23-35.

3. Mineral Commodity Summaries 2015; U.S. Department of the Interior: Washington, DC, USA., 2015, 156-157.

4. Griebel, J.J.; Glass, R.S.; Char, K.; Pyun, A.G. J. Progress in Polymer Science., 2016, 58, 90-125

5. Zhang, J.; Shi, Y.; Ding, Y.; Zhang, W. Yuln, G. Nano Lett., 2016, 16(11), 7276-7281.

6. Zheng, C.; Niu, S.Z.; Lu, W.; Zhou, G.M.; Li, J.; Fan, S.X. Nano Energy., 2017, 33, 306-312.

7. Yang, Y.; Zheng, G.; Cui. Y. Chem. Soc. Rev., 2013, 42, 3018 - 3029.

8. Brun, N.; Sakaushi, K.; Yu, L.; Giebeler, L.; Eckert, J.; Titirici, M.M. Phys. Chem., 2013, $15,6080-6087$.
9. Zhong, X.B.; Yang, Z.Z.; Wang H.Y.; Lu, L.; Jin, B.; Zha, M. J. Power Sources., 2016, 306, 718723.

10. Ramakrishnan, P; Baek, S.H.; Park, Y.; Kim, J.H. Carbon., 2017, 115, 249-260.

11. Diez S.; Hoefling, A.; Theato, P.; Pauer, W. Polymers., 2017, 9, 59.

12. Wang, H.; Wu, Z.; Chen, M.T.; McDowell, Y.; Cui, Z. Nat. Chem., 2013, 5, 1042-1048.

13. Pat. $2434890 \mathrm{RU}$, publ. 27.11.2011 Bull. number 33. Corjova, S.A.; Trofimov, B.A.; Malkina, A.G.; Nosyreva, V.V.; Prozorova, G.F.

14. Fang, R.; Zhao, S.; Hou, P.X.; Cheng, M.; Wang, S. G.; Cheng, H.M.; Liu, C.; Li, F. Adv. Mater., 2016, 28, 3374-3382.

15. EunHyun, J.; Lee, J.; Tatsumi, I. Electrochimica Acta., 2015, 176, 887-892.

16. Yang, Y.; Zheng, G.; Cui, Y., Chem. Soc. Rev., 2013, 42, 3018.

17. Lin, Z.; Liang, C. J. Mater Chem. 2015, 3, 936. 